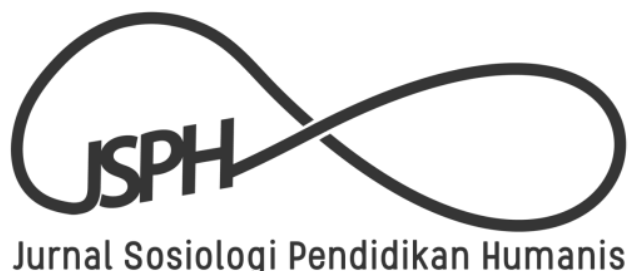

\title{
KAMPUS DAN DEGRADASI PENGETAHUAN POLITIK MAHASISWA
}

\author{
Abdus Sair \\ Program Studi Sosiologi FISIP Universitas Wijaya Kusuma Surabaya (UWKS) \\ Email:abdussyair@yahoo.com
}

\begin{abstract}
Abstrak
Cerita sukses tentang peran mahasiswa, tentu bukan karena gerakannya saja, melainkan juga karena pengetahuannya tentang politik. Selain itu, juga karena mereka memiliki sikap politik yang rasional dan dapat dipertanggungjawabkan. Kini cerita sukses tersebut tinggal cerita, sebab pengetahuan politik mahasiswa mulai menurun (degradasi), sikap mereka juga cenderung apatis. Tulisan ini menggunakan pendekatan kualitatif sebagai pijakan penelitian dengan teknik pengambilan data wawancara, observasi dan tinjauan pustaka. Oleh karena itu, melalui tulisan ini, akan dijelaskan bagaimana pengetahuan politik mahasiswa terhadap penyelengaraan pemilu dewasa ini, peran mereka dalam pemilu, pengetatahuan mereka terhadap figur dan kekuasaan partai politik, serta pengetahuan mereka terhadap figur dan profil calon presiden tahun 2014.
\end{abstract}

Kata Kunci: mahasiswa, pengetahuan politik, degradasi

\section{CAMPUS AND STUDENT POLITICAL KNOWLEDGE DEGRADATION}

\begin{abstract}
Success stories on the role of students, certainly not because the movement, but also for his knowledge of politics. Moreover, also because they have a political attitude that is rational and accountable. Now the success story of the living story, because political science students started to decrease (degradation), they also tend to be apathetic attitude. This paper uses a qualitative approach as the basis of research with data collection techniques of interview, observation and literature review. Therefore, through this article, I will explain how students' political knowledge of the election administration today, their role in the election, they knowledge against authority figures and political parties, as well as their knowledge of the figures and profiles of presidential candidates in 2014.
\end{abstract}

Keywords: students, political knowledge, degradation 


\section{LATAR BELAKANG}

Kampus dan mahasiswa adalah dua hal yang berbeda, namun keduanya tak bisa dipisahkan. Kampus adalah institusi yang mereproduksi pengetahuan politik. Sementara mahasiswa menjadi penghuni didalamnya. Di kampus, segala macam pengetahuan (termasuk pengetahuan politik), dirumuskan lalu diperdebatkan untuk mencari kebenaran. Karena itu, kampus dan mahasiswa selalu dianalogikan sebagai lokomotif intelektual yang memiliki kekuatan politik yang disegani. Dalam sejarah politik bangsa Indonesia, kampus dan mahasiswa telah menjadi pendorong bagi elit bangsa untuk merumuskan sistem politik yang akan digunakan. Pada masa Orde Lama (Orba) misalnya,kampus menjadi tempat diskursus tentang model pemerintahan dan sistem politik Indonesia. Hasilnya, pada tahun 1955, diskursus tersebut telah mendorong penyelenggaraan pemilu pertama Indonesia.

Hal yang sama pada masa Orde Baru (Orba), kampus menjadi tempat reproduksi pengetahuan politik, kemudian berkembang menjadi gerakan pengoreksi atas rezim yang berkuasa. Bahkan setelah pemilu tahun 1971, kampus dan mahasiswa terus maju seiring dengan kemajuan masyarakat. Mereka menjadi penggerak untuk mengawasi penyelenggaraan baru negara, terutama terkait dengan penggunaan strategi pembangunan yang diambil pemerintah, seperti masalah korupsi PERTAMINA, pemborosan dana negara lewat pembangunan Taman Mini dan sebagainya.

Lewat kampus pula, pengetahuan politik mahasiswa tak ada akhirnya. Mereka kian berani membentuk komite-komite dan menginstruksikan penghematan uang negara dan rasionalitas strategi pembangunan nasional. Upaya ini sempat menimbulkan kemarahan bagi pemerintah. Melalui kekua- saannya, pemerintah melalukan pendudukan terhadap kampus, dan membuat kebijakan yang dikenal dengan Normalisasi Kehidupan Kampus (NKK). Kebijakan yang diambil Menteri Pendidikan dan Kebudayaan waktu itu melalui SK No.0156/U/1978 tentang Normalisasi Kehidupan Kampus dan disusul dengan SK No.037/U/1979 tentang Badan Koordinasi Kemahasiswaan (BKK). Hal ini dilakukan karena mahasiswa dianggap terlalu jauh mengurusi urusan politik. Kebijakan itu berhasil menyumbat kampus dan mampu "mensterilkan" politik mahasiswa terhadap pemerintah. Kondisi ini bertahan hingga pada pemilihan umum tahun 1997.

Kemaharan pemerintah lewat kebijakan represif itu akhirnya memunculkan kembali aksi-aksi politik mahasiswa. Puncaknya pada tanggal 20 Mei 1998, gerakan reformasi muncul sebagai refleksi pengetahuan politik mahasiswa. Soeharto sebagai simbol kekuatan Orde Baru yang berkuasa lebih dari 32 tahun dipaksa turun ke peraduannya. Sejak itulah, kampus dan pengetahuan politik mahasiswa menjadi cermin standar riil kekuatan mahasiswa dalam politik nasional, hingga menghasilkan era pemerintahan baru, yang dikenal dengan pemerintahan reformasi. Pemerintahan reformasi adalah hasil tuntutan mahasiswa melalui pemilu 1999, yang di dianggapnya paling demokratis, transparan, luber (langsung, umum, bebas, rahasia) dan jurdil (jujur adil) (Siswati, 1999).

Namun belakangan ada problem, setelah satu dekade reformasi berjalan, peran mahasiswa dalam politik di atas dianggap menurun. Gerakan mahasiswa sebagai representasi pengetahuan politik mahasiswa juga dinilai kian degradasi yang dibuktikan dengan rendahnya peran mereka dalam mengawal dan mengoreksi kebijakan 
pemerintahan. Singkatnya, mahasiswa dianggap mulai sibuk dengan urusan pribadinya dibandingkan dengan sibuk urusan organisasi. Mahasiswa hanya kuliah dan tidak menjadi pusat gerakan yang selalu diposisi pengawas pemerintahan layaknya di masa lalu. Demikian juga pengetahuan mereka terhadap politik dianggap kian sempit bahkan cenderung apatis. Padahal apatisme mereka berbahaya bagi kelanjutan politik bangsa Indonesia.

Oleh karena itu, tulisan berbasis penelitian ini akan menjelaskan bagaimana pengetahuan politik mahasiswa terhadap penyelengaraan pemilu dewasa ini, peran mereka dalam pemilu, pengetahuan mereka terhadap figur dan kekuasaan partai politik, serta pengetahuan mereka terhadap figur dan profil calon presiden tahun 2014. Ini penting untuk menjawab dugaan publik selama ini terhadap mahasiswa, apalagi mereka terlanjur disebut agent of social control, andiron stock, yang sering dimaknai sebagai penyambung lidah rakyat untuk mengontrol dan mengawasi berbagai kebijakan pemerintah, pelopor terwujudnya perubahan sosial yang lebih baik, serta sebagai calon penerus generasi kepemimpinan bangsa di masa mendatang.

\section{METODE PENELITIAN}

Dalam penelitian artikel ini digunakan pendekatan kualitatif yang sifatnya naturalistik untuk mengungkap fenomena tentang degradasi pengetahuan politik mahasiswa. Teknik pengumpulan data dilakukan dengan wawancara yang diambil secara purposive. Observasi dan kajian kepustakaan juga dilakukan dalam penelitian ini yang dilakukan pada September 2014.

\section{HASIL DAN PEMBAHASAN Mahasiswa dan Kultur Kampus Saat Ini}

Mahasiswa adalah panggilan bagi mereka yang sedang menuntut ilmu di perguruan tinggi, baik negeri maupun swasta atau lembaga lain yang setingkat dengan perguruan tinggi. Fachry Ali mengartikan mahasiswa sebagai dunia anak muda terpelajar yang berkesempatan menikmati pendidikan di Perguruan Tinggi ataupun akademi. Sebagai dunia anak muda, mahasiswa memiliki etos tersendiri serta pola-pola hubungan yang khas (Fachry Ali, 1985).

Konsep lain juga dijelaskan Francois Railon dalam bukunya Politik dan Ideologi Mahasiswa Indonesia (1985). mahasiswa dikatakan sebagai kelompok anak muda yang memiliki kesamaan cita-cita dan memainkan peranan yang menentukan pada saat-saat terpenting di dalam sejarah Indonesia. Konsepsi ini dikaitkan dengan peranan mahasiswa dalam mewujudkan citacita bangsa Indonesia. Disinilah kemu-dian mahasiswa dianggap sebagai kelompok kalangan muda yang memiliki peranan dan identitas diri yang memungkinkan mereka menyampaikan dan memper- tahankan pandangan-pandangan mereka (Francois Raillon, 1985).

Dalam sejarah perjalanan Indonesia, mahasiswa memang memiliki peranan yang sangat penting. Dimulai sejak masa kolonial tahun 1908 dan tahun 1928, mahasiswa sebagai generator kebangkitan nasional. Masa penjajahan Belanda dan Jepang sebagai pejuang kemerdekaan. Sementara pada masa Orde Lama, Orde Baru dan Orde Reformasi, mahasiswa sebagai elemen pengoreksi dari rezim yang berkuasa. Keseluruhan untaian waktu itu memberikan catatan penting bagi mahasiswa sebagai kelompok intelektual. 
Namun, cerita sukses atas peran mahasiswa di atas, tidak muncul begitu saja, melainkan karena didukung oleh kultur akademik kampus yang mapan, Sebagai mana diketahui, kampus-kampus di masa lalu telah banyak melahirkan generasi baru, dan memiliki langkah lebih jauh dalam membawa obor perjuangan kemerdekaan dan kemajuan. Mahasiswa angkatan '66 misalnya, lahir karena tradisi intelektual yang tinggi, maskipun tidak didukung dengan kondisi ekonomi yang mapan. Disaat bersamaan, ada faktor radikalisasi politik mahasiswa, dan lahirnya peristiwa PKI di akhir tahun '65 dan diawal ' 66. Faktor dominan lainnya adalah karena ada dua kekuatan besar yang mempengaruhi mahasiswa saat itu. Pertama, Lembaga Kebudayaan Rakyat (Lekra), Kedua, pengaruh kampus-kampus Amerika.

Lekra berpengaruh terhadap kehidupan intelektual mahasiswa karena dianggap memiliki hubungan erat dengan PKI, dan berusaha memaksanaan pandangan-pandangan mereka dalam bidang kesenian, kesusasteraan dan gagasan-gagasan dengan pendekatan "realisme kritis" atau "romantisme revolusioner". Sementara kampuskampus Amerika berusaha mempengaruhi dengan cara memberi beasiswa kepada kampus-kampus Indonesia. Universitas Indonesia (UI) dan Institut Teknologi Bangung (ITB) adalah dua lembaga yang menerinta bantuan Amerika itu.

Kini dengan kondisi yang berbeda, kampus-kampus Indonesia telah banyak berdiri, dengan fasilitas yang memadai juga. Dukungan pemerintah terhadap pengem bangan kampus juga sangat tinggi. Namun demikian, situasinya tetap berbeda. Situasi kampus saat ini dinilai tak lebih sekedar industri untuk mencetak para pekerja, bukan pemikir yang diproduksi dengan tradisi intelektual yang mapan. Sistem pendidikan yang membuat paketpaket kelulusan adalah bukti kampus telah menjadi industri sebagaimana disinggung di atas.

Kultur akademis yang sejatinya menjadi ciri khas dunia kampus juga akhirnya ikut melebur menjadi kultur akademi hibu ran yang melibatkan sederet mahasiswi. Apa yang dipakai di tubuhnya menjadi identitas tunggal dan dominan, sehingga kampus menjadi semacam panggung pertunjukan untuk merepresentasikan dirinya sebagai mahasiswa "unggul". Mahasiswa unggul bukan lagi ditentukan sebe-rapa banya karyanya, namun ditentukan oleh seberapa banyak simbol-simbol buda-ya pop yang digunakan. Meminjam istilah Ritzer, kampus telah menjadi McLectures dan Mc Colleges, sebuah kritik atas kampus yang ter-McDonaldisasi. Cara mahasiswa mem per lakukan dosennya, seolah-olah me-reka pekerja di industri cepat saji. Jika mere-ka tak puas, mereka juga memiliki kebebasan untuk mengeluh (George Ritzer, 2014), adalah bukti lain bahwa kampus mirip seperti industri.

Secara umum, dampaknya adalah ada perubahan intelektual yang ditandai dengan ukuran output karya ilmiyah yang dihasil kan, serta ada penurunan pemahaman dan gerakan politik yang ditunjukkan. Maha siswa mulai cenderung enggan berbeda pen dapat, berdebat, bersaing, dan berambisi dalam kemajuan.Atmosfir tata nilai ini lebih jauh membuat kampus cenderung statis, tidak ada lagi pergulatan inovasi bagi para intelektual kampus guna menemukan teoriteori baru. Demikian juga soal pema haman politik, mahasiswa cenderung diam, tak mau berorasi, turun ke jalan, memper juangkan kepentingan rakyat kebanyakan. Sehingga peran mereka dalam politik menjadi 
dipertanyakan? Sebagian orang kemudian bertanya-tanya, kemana mahasiswa?

\section{Pengetahuan Mahasiswa Tentang Pemilu}

Di internal mahasiswa ada banyak pandangan tentang fungsi dan kedudukan mereka. Sebagian menilai begini, mahasiswa harus aktif di segala bidang, termasuk tidak apatis terhadap kenyataan yang ada. Mahasiswa harus memperjuangkan rakyat yang "terpinggirkan" oleh kebijakan pemerintah yang tak memihak. Mahasiswa jangan sekedar menyibukkan diri dengan urusan pribadinya di luar. Melainkan harus meng ikuti perkembangan politik yang ada, sebab ia adalah agen perubahan ${ }^{1}$

Sebagian yang lain menilai bahwa, mahasiswa harus belajar terlebih dahulu. Jangan terlalu banyak mengurusi urusan politik, apalagi sampai terlibat di dalamnya secara langsung. Mahasiswa masih memiliki tanggung jawab diri untuk belajar sebagai pelaku intelektual. Ia harus memiliki kemampuan akademik yang mapan. Namun, pandangan ini juga setuju bahwa, belajar tak berarti hanya sekedar pergi ke kampus lalu pulang, melainkan juga harus mau belajar berorganisasi, baik di kampus maupun di luar kampus ${ }^{2}$.

Merujuk pada kedua pendapat di atas, ada satu pandangan yang sama bahwa mahasiswa harus mereproduksi diri sebagai kelompok intelektual. Mereka harus belajar de-ngan segala kemampuannya. Nilai-nilai ideal budaya kampus juga sejatinya melekat pada dirinya, yang ditunjukkan dengan selalu aktif membaca, menulis dan berdiskusi, serta aktif berorganisasi. Lebih-lebih

1 Hasil wawancara dengan Leo Wira hardiono (Mahasiswa Bahasa Indonesia FBS), tanggal 24 September 2014

2 Hasil wawancara dengan Moh. Hosen, mahasiswa matematika FBS, 24 Sepetember 2014 jika selalu aktif untuk meng-update soal perkembangan politik yang ada. Mengingat mereka adalah bagian dari kekuatan civil society.

Namun di lapangan tidaklah demikian, tidak semua mahasiswa ternyata mampu menjalankan nilai-nilai ideal tersebut. Disadari atau tidak, ada kecenderungan sebagian besar mahasiswa memilih mengedepankan aspek kesenangan dalam kehidupan ilmiah kampus. Mereka cenderung apatis terhadap urusan politik, apalagi urusan publik. Hanya sebagian kecil mahasiswa yang masih memiliki sense of crisis terhadap urusan tersebut.

Fakta ini dapat dilihat dari pengetahuan mereka terhadap Pemilihan Umum (Pemilu) 2014. Sebagai momen pergantian kepemimpinan nasional, pemilu 2014 ternyata tidak menjadi isu sentral di kalangan mahasiswa. Sebagai agent of social control, andiron stock, yang dimaknai sebagai penyambung lidah rakyat untuk mengontrol dan mengawasi pemilihan, nampaknya kian bergeser. Sebagian besar mahasiswa ternyata memilih untuk mainmain. Hanya sebagian kecil mahasiswa yang memilih memikirkan nasib bangsa melalui pemilu 2014. Padahal kehadiran mereka begitu penting untuk kebaikan bangsa ini.

Sebagian besar mahasiswa juga tahu bahwa 9 April dan 9 Juli 2014 adalah pemilihan umum untuk memilih anggota dewan (DPR) dan memilih presiden serta wakilnya. Namun pengetahuan mereka tidak diperoleh melalui proses diskursus yang panjang. Mereka kini seperti rakyat biasa, menjadi sasaran para kandidat, bahkan juga menjadi objek pemilihan dimana kehadiran dan suaranya dibutuhkan di bilik suara. Padahal, dimasa lalu, mereka menjadi subyek yang memberi pola,dan 
mengawasi jalannya pemilihan. Selain itu, mereka juga merespon pemilu dengan sikap pasrah, siapapun yang akan menjadi presiden Indonesia, tidak menjadi masalah yang penting dapat merubah keadaan. Sebagai mahasiswa, mereka menjalani proses ini, kemudian kelak setelah tamat dapat menikmati pekerjaan.

Kenyataan ini menggambarkan bahwa pengetahuan politik mahasiswa kian menurun. Posisi mereka juga demikian, seperti tak memiliki tada tawar, yang dulu sebagai subyek, menjadi sekedar objek. Menurut Marcus dan MacKuen (1993), kelompok intelektual macam mahasiswa sejatinya merespon pemilu dengan emosi-emosi yang spesifik, berupa antusiasme dan kecemasan. Respon antusiasme adalah untuk mempengaruhi keputusan kepada siapa suara akan diberikan. Sedangkan kecemasan mempengaruhi individu untuk mencari informasi lebih mengenai kandidat yang ada. Oleh karena itu, rasa kecemasan yang dialami oleh mereka sejatinya mempunyai peran penting dalam pemrosesan informasi dan juga akan menstimulasi pembelajaran (Cottam, 2012). Karena itu, sebagai kelompok intelektual, mereka punya kewajiban terlibat dalam sistem politik negaranya sendiri dan terlibat dalam pengambilan keputusan. Singkat kata, apatisme yang ditunjukkan oleh beberapa kelompok mahasiswa di atas merupakan cerminan perasaan kewargaan yang rendah.

Sedikitnya ada dua faktor kenapa pengetahuan politik mahasiswa menjadi turun. Pertama karena faktor internal yang berasal dari dalam individu mahasiswa sendiri. Kedua karena faktor eksternal. Faktor eksternal bisa dilihat dari gejala meluasnya pengaruh dari luar semacam budaya populer (budaya pop) yang mengharu biru mempengaruhi sikap dan perilaku maha- siswa masa kini. Budaya pop sebagaimana dipahami kian meluas bersamaan dengan melu-asnya industrialisasi, perkembangan media massa, alat telekomunikasi dan sebagainya, sehingga membius kalangan anak muda termasuk mahasiswa untuk selalu menjadi bagian di dalamnya. Substansi budaya ini adalah kesenangan, konsumtif, individualistik, dan kedangkalan.

\section{Peran Mahasiswa Dalam Pemilu}

Menghubungkan peran mahasiswa dalam pemilu, bukan berarti membawa suasana pada masa lalu yaitu menyeret mahasiswa sebagai warga kampus melakukan politik praktis sebagai ajang perebutan dukungan politik terhadap salah satu calon kandidat yang akan maju dalam pemilihan umum, melainkan lebih pada sebagai agen perubahan sosial untuk mendorong terjadinya transformasi sosial politik dengan mengedepankan pendidikan politik yang rasional dalam perspektif pengembangan demokratisasi dalam kemajuan masyarakat.

Peran tersebut dapat dimainkan oleh mahasiswa sebagai warga kampus yang secara umum dapat disebutkan sebagai berikut; Pertama, sebagai sumber insani pembangu-nan dengan menjadi kader-kader bangsa yang handal secara leadership (kepemimpinan-manajemen organisasi), Kedua, kemampuan intelektual sehingga dengan ilmu dapat mendiagnosa (menterapi) kebutuhan-kebutuhan terhadap problem kebangsaan, Ketiga, mempunyai dedikasi dan moralitas yang tinggi untuk menegakkan aturan dan tata perundangundangan serta etika moral, Keempat, gerakan politik yang kekuataanya diakui sebagai gerakan moral di setiap orde pemerintahan. 
Dari keempat peran mahasiswa di atas, gerakan moral politik mahasiswa jelas telah terbukti membawa perubahan bagi bangsa Indonesia. Pada awal kemerdekaan misalnya, mahasiswa telah mendorong kelompok Bung Tomo di Surabaya mengobarkan semangat juang arek-arek Suroboyo mengibarkan bendera revolusi pada tahun 1908 hingga kemerdekaan tercapai. Pada Orde Lama peran mahasiswa dari berbagai kampus berhadapan dengan Partai Komunis Indonesia (PKI). Sementara pada masa Orde Baru, peran mahasiswa sebagai kaum intelektual mendorong munculnya perubahan sosial, kemudian lahirlah apa yang dikenal dengan reformasi. Tak hanya itu, mahasiswa juga mengawal secara langsung jalannya pemilihan umum 1999, sebuah pemilihan yang dianggap paling demokratis. Mahasiswa menjadi perumus, pelaksana dan pengawas pemilihan, sehingga lahirlah pemerintahan reformasi.

Namun, kisah sukses tersebut tidak ditemukan pada mahasiswa sekarang. Penelitian ini mengkonfirmasi bahwa peran mahasiswa dalam pemilu 2014 tidak begitu penting. Mereka tidak menjadi bagian terpenting dalam momen pergantian kepemimpinan nasional. Misalnya menjadi perumus, pengawas, menjadi panitia pemilihan, dan sebagainya. Peran-peran tersebut justru banyak dipegang oleh masyarakat umum. Sementara mahasiswa hanya menjadi pemilih biasa. Kondisi ini karena mahasiswa menilai pemilu bukanlah agenda mahasiswa, melainkan agenda negara. Sikap ini tentu mendegradasi peran mereka sebagai kelompok intelektual.

\section{Pengetahuan Mahasiswa terhadap Figur dan Kekuasaan Partai Politik}

Bagi mahasiswa, figur dan kekuasaan partai politik adalah kunci pembangunan politik. Di tangan merekalah (elit) sebetulnya bangsa Indonesia akan berkembang atau tidak. Mereka juga sebagai penjaga stabilitas politik nasional. Jika mereka tak mampu menjamin stabilitas politik, maka bisa diprediksi pembangunan nasional akan menjadi terganggu. Dampaknya bisa akan mempengaruhi pembangunan dan kesejahteraan rakyat. Oleh karena itu mereka disebut elit karena keberadaanya diharapkan menjadi penghubung antara rakyat dengan pemerintah.

Apa yang dipahami sebagai figur dan kekuasaan partai politik oleh mahasiswa adalah sama dengan pemahaman publik pada umumnya. Mereka dianggap elit karena keberadaanya dibutuhkan oleh masyarakat secara umum. Fungsi mereka tidak sekedar stratifikasi kekuasaan, melainkan memiliki fungsi sosial yang dibutuhkan bagi hajat hidup orang banyak. Mereka disebut elit juga bukan karena banyak uangnya, melainkan karena memiliki kemampuan dan kelebihan untuk memimpin masyarakat. Itu sebabnya, secara sosiologis, disebutkan bahwa seorang elit atau figure partai politik muncul karena melalui dinamika yang berlangsung di dalam masyarakat. Mereka diasah, belajar, dan dibesarkan oleh masyarakatnya sendiri (Bustami dan Yuswadi, 2004).

Namun, penilaian mahasiswa terhadap figur dan kekuasaan partai politik di atas masih sangat minor. Penelitian ini menggambarkan bahwa figur partai politik dinilai kurang bisa dipercaya. Alasannya, karena mereka menjadi elit partai bukan untuk kepentingan rakyat melainkan untuk kepentingan mereka sendiri, termasuk untuk kepentingan kelompok dan partainya ${ }^{3}$. Pandangan ini dipengaruhi oleh banyaknya peri-

3 Hasil wawancara dengan dengan Dave Rindy, tanggal 24 Seprtember 2014 
laku elit partai yang mencederai hati nurani rakyat. Apalagi mereka dianggap bukan menjadi wakil rakyat melainkan lebih sebagai wakil partai. Selaras dengan ini, hasil survey Center for Strategic and International Studies (CSIS) pada tahun 2012, juga menunjukkan hal yang sama, bahwa kepercayaan publik terhadap elit partai kian menurun, yakni hanya dikisaran 22,4 persen. Demikian juga soal dukungan publik terhadap partai politik, terus menurun, yang disebabkan oleh fungsi partai politik yang dinilai berubah. Parpol dianggap bukanlah institusi yang menjadi saluran buat aspirasi publik ke pemerintah, melainkan lebih menjadi alat buat elit-elit politik untuk mencapai kekuasaan.

Menurut mahasiswa, kondisi elit parpol di atas disebabkan karena mereka tidak sungguh-sungguh sebagai wakil rakyat. Mereka hanya sekedar mendapatkan kekuasaan, tetapi tidak untuk pengabdian. Mereka menjadi elit parpol karena banyak melakukan pencitraan, bukan pada pengabdian yang sesungguhnya ${ }^{4}$. Padahal, menjadi elit partai harus sepenuhnya murni, dan tidak dibuat-buat, atau seolah-olah baik, tetapi faktanya tidak. Selain itu, belbagai perilaku korup yang dilakukan oleh elit partai juga menjadi faktor penilaian minor mahasiswa. Dipo Alam (Sekretaris Kabinet masa pemerintahan SBY-Boediono), pernah menyebutkan ada 176 orang pejabat Negara dan anggota dewan yang terlibat kasus hukum. Dari jumlah tersebut 79\%-nya merupakan kasus korupsi dan sisanya kasus pidana lainnya.

Fakta inilah yang barangkali membuat persepsi di kalangan mahasiswa terhadap elit dan kekuasaan partai politik cenderung negatif.

4 Hasil wawancara dengan dengan Dave Rindy, tanggal 24 Seprtember 2014

\section{Pengetahuan Mahasiswa Terhadap Figur dan Profil Calon Presiden}

Bagi mahasiswa, demokrasi sejatinya dapat menemukan pemimpin yang baik, yang mampu merangkul semua orang. Di bawah ini, akan dipaparkan pengetahuan atau pan-dangan mahasiswa soal figur pemimpin Indonesia mendatang. Menurutnya, masalah penting yang dihadapi bangsa Indonesia adalah perkara pluralisme yang bisa meng-ancam kehidupan berbangsa dan bernegara. Konflik antar suku, antar agama, dan antar ras adalah perkara lama yang tak pernah surut dari bumi pertiwi ini $^{5}$. Indonesia butuh pemimpin yang mampu menggerakkan instrumen negara untuk menangani masalah tersebut secara damai. Pemilihan presiden adalah moment penting untuk mencari pemimpin itu, membuat kontrak sosial, dan berkomitmen untuk menjamin bahwa pluralisme bangsa ini tetap terjaga dengan baik.

Selanjutnya adalah pemimpin yang mengerti tentang penderitaan rakyat. Disadari atau tidak, rakyat dianggap masih banyak yang miskin, jutaan orang masih berada di jurang itu. Mereka sulit mencari makan, bahkan ada diantara mereka yang kelaparan. Mereka hidup hanya mengandalkan rasa iba dari orang lain, mereka juga meminta-minta, di pinggir jalan, rumah ke rumah, ada juga yang sambil mengamen, dan sebagainya. Penderitaan itu dinilainya hanya dirasakan oleh rakyat sendiri, para pemimpin seringkali lupa tentang penderitaan tersebut. Para pemimpin umumnya sibuk mengurusi diri sendiri. Karena itu, Indonesia butuh pemimpin yang mengerti keadaan rakyat tersebut, mau bekerja demi merubah keadaan, bukan hanya janji, melainkan bukti. Mereka juga punya konsep

5 Hasil wawancara dengan informan 
dan cara bagaimana mengeluarkan masyarakat dari jaring kemiskinan itu, sehingga Indonesia punya harapan untuk masa depan yang lebih baik ${ }^{6}$.

Hal lain adalah Indonesia butuh pemimpin yang tegas, berani mengatakan yang benar dan yang salah. Menegakkan hukum bagi pelaku korupsi. Tidak hanya ngomong doang, tapi benar-benar menerapkannya. Selama ini belum ada pemimpin yang memiliki karakter itu. Yang ada hanya penguasa dimana kerabat dan kroninya banyak melakukan korupsi. Katakan tidak pada korupsi, tapi ternyata melakukan korupsi. Indonesia harus mencari pemimpin yang berani tampil di depan dalam perkara korupsi, siapapun itu, ia mau menegakkan keadilan. Bangsa ini sudah terlanjur rapuh akibat perilaku korupsi. Korupsi adalah kejahatan yang luar biasa. Indonesia sulit berkembang karena perkara ini. Kekayaan Indonesia menjadi percuma, karena selalu digerogoti oleh tangan dan mulut yang rakus yang berdasi, umumnya mereka berada di istana dan senayan sana. Rakyat Indonesia hanya menikmati ceritanya saja, tanpa menikmati kekayaan yang sebenarnya.

Syarat lain menurut mahasiswa adalah pemimpin yang memiliki inovasi untuk mengembangkan pertanian kita. Sungguh sedih melihat negara selaus dan sekaya ini, malah tidak mampu memenuhi kebutuhannya sendiri. Semuanya serba impor, daging, beras, gula, garam, apel, jeruk, dan segala kebutuhan lainnya. Kondisi ini ditengarai karena ada yang salah dengan pemimpin bangsa ini. Indonesia butuh pemimpin yang mampu membuat kebijakan pro pertanian, bukan bias terhadap masalah perkotaan. Mau memberikan subsidi kepada para

6 Hasil wawancara dengan Angga Dwi Setya, Mahasiswa Sosiologi Fisip UWKS pada tanggal 26 September 2014 petani, memberi bibit unggul, menjaga agar lahan pertanian tidak tergerus oleh pembangunan, seperti pembangunan properti, dan sebagainya. Pemimpin yang pro pertanian itu juga kreatif, mampu memberikan jalan keluar atas masalah harga pertanian, yang umumnya dibeli murah oleh para pedagang. Mampu mendorong tumbuhnya perekonomian para petani dengan infrastruktur pertanian yang memadai, serta berkomitmen penuh untuk menjunjung tinggi martabat para petani ${ }^{7}$.

Berikutnya adalah pemimpin yang memiliki kapasitas diri bersaing dengan pemimpin global. Mereka mampu membawa bangsa ini berdaya tawar tinggi, sehingga mampu disegani oleh bangsa lain. Tidak seperti sekarang, negara sering kali dintervensi oleh bangsa asing, NKRI masih "diinjak", wilayah kita masih di tabrak, dan kekayaan kita masih dicuri. Anehnya pemimpin kita masih tenang-tenang saja. Kita butuh pemimpin yang tegas terhadap bangsa lain yang berusaha mengganggu keutuhan bangsa ini. Selain itu, Indonesia butuh pemimpin yang mampu mengangkat martabat bangsa ini, bukan secara citra, melainkan secara fakta.

Terakhir, menurutnya Indonesia butuh pemimpin yang mau hidup sederhana, tidak glamour, apa adanya, namun punya integritas tinggi, selain itu juga mampu menjadi contoh bagi yang lain. Bangsa ini butuh pemimpin yang demikian, karena Indonesiasedang mengalami krisis nilai, krisis moral, dan krisis contoh pemimpin yang baik ${ }^{8}$.

7 Hasil wawancara dengan Siti Aminah, mahasiswa akuntansi UWKS, 30 September 2014

8 Hasil wawancara dengan Moh. Husen, mahasiswa matematika UWKS, tanggal 30 September 2014 


\section{KESIMPULAN}

Pengetahuan politik mahasiswa terhadap pemilu 2014 cenderung degradatif, ini karena mereka sekedar tahu bahwa bangsa ini akan melakukan pergantian kepemimpinan nasional, mereka tidak punya ide dan giroh bagaimana memilih, mendorong dan membangkitkan masyarakat untuk menentukan siapa yang akan dipilih. Faktanya, mereka cenderung menjadi "penonton" yang terbuai oleh situasi politik dimana mereka tidak mampu membangkitkan dirinya sebagai agen perubahan. Ada dua faktor kenapa posisi ini menjadi demikian; Pertama faktor internal yakni sistem pendidikan yang dekonstruktif terhadap fungsi mahasiswa. Sistem pendidikan termasuk lembaga pendidikan di dalamnya kian dibentuk seperti lembaga makanan siap saji. Mahasiswa didorong untuk cepat lulus tanpa mempertimbangkan kualitasnya. Mereka menjadi lemah tak berdaya, kultur akademis seperti kritis, dialogis, emansipatoris dan sebagainya menjadi menipis. Kedua faktor eksternal, yaitu kemajuan teknologi informasi dan kemajuan gaya hidup juga telah menghipnotis mahasiswa untuk tidak "sadar". Mahasiswa lebih cenderung main game, jalan-jalan, dan nonton dibandingkan dengan membaca buku, berdiskusi dan menulis. Dua faktor inilah yang mendorong pengetahuan politik mahasiswa cenderung turun.

Kedua, Keterlibatan mahasiswa da-lam Pemilu 2014. Secara umum penelitian ini menemukan bahwa mahasiswa hanya menjadi pemilih biasa. Mereka tidak menjadi bagian penting dalam momen pergantian kepemimpinan nasional. Peranperan penting justru banyak dipegang oleh masyarakat umum. Kondisi ini karena mahasiswa menilai pemilu bukanlah agenda mahasiswa, melainkan agenda Negara.
Penilaian ini kemudian mendegradasi peran mahasiswa sebagai agen perubahan.

Ketiga, Pandangan mahasiswa terhadap figur dan kekuasaan partai politik. Penelitian ini menggambarkan bahwa figur partai politik cenderung kurang dapat dipercaya. Mereka dianggap elit tapi fungsinya bukan untuk kepentingan rakyat melainkan untuk kepentingan sendiri, termasuk untuk kepentingan kelompok dan partainya. Gambaran ini karena banyak perilaku elit partai yang mencederai hati nurani rakyat, misalnya perilaku korupsi. Korupsi yang dilakukan elit partai sudah sangat mengkhawatirkan, tidak hanya di pusat, melainkan juga di d aerah. Jumlah uang yang dikorupsi tidak sedikit, namun mencapai milyaran rupiah

Keempat, Pandangan mahasiswa terhadap figur dan profil calon Presiden 2014. Ada beberapa figur calon presiden yang sangat diidamkan, (1) Ia pemimpin yang baik, yang mampu merangkul semua orang. Alasannya bangsa ini masih memiliki masalah penting yang harus dihadapi yakni perkara pluralisme yang bisa mengancam kehidupan berbangsa dan bernegara. Konflik antar suku, konflik antar agama, dan konflik antar ras adalah perkara lama yang tak pernah surut dari bumi pertiwi ini. Dibutuhkan pemimpin yang mampu menggerakkan instrumen negara untuk menangani masalah tersebut secara damai.

(2) Ia mengerti tentang penderitaan rakyat. Disadari atau tidak, rakyat masih banyak yang miskin, jutaan orang masih berada di jurang itu. Mereka sulit mencari makan, bahkan ada diantara mereka yang kelaparan. Mereka hidup hanya mengandalkan rasa iba dari orang lain, mereka juga meminta-minta, di pinggir jalan, rumah ke rumah, ada juga yang sambil mengamen 
dan sebagainya. (3) Ia pemimpin yang tegas, berani mengatakan yang benar dan yang salah. Menegakkan hukum bagi pelaku korupsi. Hingga kini belum ada pemimpin yang memiliki karakter demikian. Yang ada hanya penguasa dimana kerabat dan kroninya banyak melakukan korupsi. Katakan tidak pada korupsi, tapi nyatanya masih melakukan korupsi. Bangsa ini butuh pemimpin yang berani tampil di depan dalam perkara korupsi untuk menegakkan keadilan demi kemaslahatan rakyat Indonesia.

(4) Ia seorang pemimpin yang memiliki inovasi untuk mengembangkan pertanian, sehingga tidak selalu impor. Faktanya, negara selaus dan sekaya ini, malah tidak mampu memenuhi kebutuhan rakyat sendiri. Semuanya serba impor, mulai daging sapi, beras, gula, garam, apel, jeruk, hingga pakaian dalam wanita dan pria. Bangsa ini butuh pemimpin yang mau dan mampu membuat kebijakan pro pertanian, bukan bias terhadap masalah perkotaan. Mau memberikan subsidi kepada para petani, memberi bibit unggul, menjaga agar lahan pertanian tidak tergerus oleh pembangunan, seperti pembangunan properti, dan sebagainya. Pemimpin yang pro pertanian itu juga kreatif, mampu memberikan jalan keluar atas masalah harga pertanian, yang umumnya dibeli murah oleh para pedagang. Mampu mendorong tumbuhnya perekonomian para petani dengan infrastruktur pertanian yang memadai, serta berkomitmen penuh untuk menjunjung tinggi martabat para petani.

(5) Ia seorang pemimpin yang memiliki kapasitas diri bersaing dengan pemim-pin global. Mereka mampu membawa bangsa ini berdaya tawar tinggi, sehingga mampu disegani oleh bangsa lain. Ia juga tidak mau di-intervensi oleh bangsa lain demi martabat bangsa Indonesia. (6) Pemimpin yang mau hidup sederhana, tidak glamour, apa adanya, namun punya integritas tinggi.

\section{DAFTAR PUSTAKA}

Ali, Fachry. (1985).Mahasiswa, Sistem Politik Indonesia dan Negara. Jakarta. Inti Sarana Aksara.

Firmansyah(2008). Marketing PolitikAntara Pemahaman dan Realitas. Jakarta. Yayasan Obor Indonesia.

Hidayat, Dedy. (1999). Jurnal Ikatan Sarjana Komunikasi Indonesia Volume 3 Nomor 1.

Kamus Besar Bahasa Indonesia (Edisi kedua).(1995). Departemen Pendidikan dan Kebudayaan.Jakarta. Balai Pustaka.

Mulyana, Deddy. (2006). Metodologi Penelitian Kualitatif. Paradigma Baru Ilmu Komunikasi dan Ilmu Sosial Lainnya. Jakarta. PT. Remaja Rosdakarya.

Rahmad, Jalaluddin. (1998). Psikologi Komunikasi. Bandung, Remaja Rosdakarya.

Raillon, Francois.(1985). Politik dan Ideologi Mahasiswa. Jakarta. LP3S

Rahman, Bustami dan Hary Yuswadi. (2004). Sistem Sosial Budaya Indonesia. Jember. Kompyawisda Jatim dan LKPM Universitas Jember

Ritzer, George. (2004). Teori Sosiologi Modern. Jakarta. Prenada Media

Ritzer, George. (2009). Sosiologi Ilmu Pengetahuan Berparadigma Ganda. Jakarta. Raja Grifindo Persada.

Robbins, Stephen P. (2007)Perilaku Organisasi Buku 1, Jakarta: Salemba Empat. 
Salim, Agus. (2006). Teori dan Paradigma Penelitian Sosial. Yogyakarta. Tara Wacana.

Siswati, (1999). Persepsi Mahasiswa terhadap Pemilu 1999, Jurnal, Tahun XII, No 3 Juli 1999

Suryanef, (2007). Persepsi Politik Mahasiswa FIS Universitas Negeri Padang, Jurnal Demokrasi Vol. X No. 2 Th. 2011

Thoha, Miftah. (1999). Perilaku Organisasi. Jakarta. CV Rajawali

\section{Website}

Republika.co.id/berita/pemilu, pada tanggal 1 Mei 2014

Riska Maya Sari, Peran mahasiswa dalam pemilu.diakses dari http://politik.kompasiana.com/2014/04 /13/peran-mahasiswa-dalam-pemilu646637.html

Seta Basri, Gerakan Mahasiswa Indonesia Sebagai Gerakan Sosial Dalam Sejarah Politik Indonesia, diakses darihttp://setabasri01.blogspot.com/20 09/02/gerakan-sosial-di-indonesiagerakan.html 